\title{
The Mediating Effect of Subjective Career Success in the Impact of Perceived Organizational Support on the Intention to Remain
}

\author{
Kemal Eroğluer1, Mustafa Bekmezci², Kenan Orçanlı² \\ ${ }^{1}$ Land War School, National Defence University, Ankara, Turkey \\ ${ }^{2}$ Faculty of Economics Administrative and Social Sciences, Toros University, Mersin, Turkey \\ Email: kerogluer@kho.edu.tr, mustafa.bekmezci@toros.edu.tr, kenan.orcanli@toros.edu.tr
}

How to cite this paper: Eroğluer, K., Bekmezci, M., \& Orçanlı, K. (2020). The Mediating Effect of Subjective Career Success in the Impact of Perceived Organizational Support on the Intention to Remain. Open Journal of Business and Management, 8, 2205-2225.

https://doi.org/10.4236/ojbm.2020.85135

Received: August 7, 2020

Accepted: September 13, 2020

Published: September 16, 2020

Copyright $\odot 2020$ by author(s) and Scientific Research Publishing Inc. This work is licensed under the Creative Commons Attribution International License (CC BY 4.0).

http://creativecommons.org/licenses/by/4.0/

\begin{abstract}
In this study, mediation role of subjective career success with regards to the relationship between perceived organizational support and intention to remain at work has been investigated. Research has been conducted on academicians assigned at foundation universities located in the cities of Ankara and Mersin which are located in Turkey. The data of the research has been collected with scales of perceived organizational support, intention to remain and subjective career success. In the study, first of all the assumptions to be provided regarding the data used in the analyzes made were checked and the test of the model that was subsequently established was made with the partial least squares-structural equation model. These analyzes were carried out with $\mathrm{R}$ programming language and SmartPLS package program. At the end of the study, it has been determined that there is a meaningful relationship in the same direction between organizational support, intention to remain and subjective career success variables, and subjective career success does not have an mediating role in the relationship between perceived organizational support and intention to remain at work.
\end{abstract}

\section{Keywords}

Perceived Organizational Support, Subjective Career Success, Intention to Remain

\section{Introduction}

Organizations are the most important actor of economical and communal sys- 
tem. The success of organizations consisting of people who come together to achieve certain goals, depends on the employees performing their duties within the organization in accordance with the determined standards. The success of the employees is not only dependent on their personal knowledge, skill and effort, and the organization should also support the employees. The fact that the employees express their opinions clearly depends on being supported by both their colleagues and managers. Employees' expressing their thoughts in decision-making processes and providing them the opportunity to participate in these processes can motivate them positively. Positive motivation can strengthen the bond between employees and their organizations, thereby increasing employee contribution and intention to remain in the organization.

Leadership quality and motivation skills of managers in creating a supportive working environment and a positive climate in the organizations bear significant importance (Dervic \& Dervic, 2017: p. 569). The attitudes and behaviors of colleagues as well as managers are the determining factors in creating this environment. It is considered that support provided by the manager being the architect of positive climate and the working colleagues, will create a positive impact on the decision of employees to continue to remain in the organization and that they will positively affect their feelings towards the organization (Beheshtifar et al., 2012: p. 432; Abou-Moghli, 2015: p. 198), while contribution of employees to the organization will increase as they feel this support (Allen et al., 2003: p. 99), and that subjective career success will be positively influenced. In the event that a positive and motivating climate cannot be created, on the contrary of employees' having the idea of staying at the organization, it can be stated that employees having the intention to leave the work will get farther away from the work, that their performance will deteriorate and this situation will create a cost particular for the organization. In this context, in this study being conducted in the education sector, mediation effect of subjective career success on the intention of academicians to remain, as constituting a group with high education level, with the provision of perceived organizational support has been investigated.

\section{Conceptual Frame}

\subsection{Perceived Organizational Support}

One of the conditions necessary for the employees to be happy and satisfied with the work they do is the support provided by the organization to the employees. This support can be provided through tangible elements such as wages, various material payments and rewards, and intangible elements such as respect, status, appreciation, equality, promotion, job security, and autonomy (Uzoğlu, 2005: p. 29). In organizational life, it is considered that the elements of intangible elements are more effective than the tangible elements in the success of the employees. Organizational support is an important factor affecting the success of employees in this context. 
Organization support has been defined as attachment of importance to welfare of employees, making contribution to the organization, by making them believe that organization values and provides support as an indicator of these particulars (Eisenberger et al., 1986: p. 501; Ring, 2011: p. 157). Kim et al. (2005: p. 171) has defined organizational support as provision of support at all levels by the organization for the training, quality, organizational procedure and operation regarding the employees, in order to increase the efficiency of the employees while they perform their activities. Özdevecioğlu (2003: p. 116) has defined organizational support as the situation where employees feel safe in the organization and feel the existence of the organization in organizational activities.

Elements such as information, tools, equipment and devices provided to the employees by the organization should also be evaluated within the scope of organizational support. In this context, organizational support can be divided into two groups namely, socio-emotional and hardware support (Zhang, 2018: p. 23). Care, respect and friendship relations to meet the social and psychological needs of employees can be counted within the scope of socio-emotional support, whereas; within the scope of hardware support, information, material and personnel support provided to help the employee complete his job can be counted.

The concept of support in working life is expressed by the support given by colleagues and leaders (Babin and Boles, 1996: p. 58). The support provided by colleagues is analyzed in two groups as emotional and financial support (Tews et al., 2013: p. 633). Within the scope of the support provided by the leaders; particulars such as improving the communication process, making employees feel valued, offering employees the opportunity to express themselves and express their opinions, and ensuring their participation in decision-making processes can be counted. It is stated that providing an environment that supports employees by both colleagues and the leader shows a positive attitude towards the work and organization of the employees and increases their job satisfaction and productivity (Kale, 2015: p. 104). Employees supported by colleagues and leaders will consider that they are embraced by their colleagues, that they can meet expectations, they are valuable, they can contribute to the organization, and that their work and themselves are valuable.

Organizational support can be explained by the norm of mutual relationship (Kestek, 2016) and the theory of social exchange (Blau, 1964). The mutual relationship norm can be summarized as the need for employees to perform the activities of the organization and the organizations to meet the needs of the employees and to generate income. Social exchange theory, on the other hand, can be expressed as voluntary activities that occur when individuals are motivated by the gain expected from the other party as a result of the exchange (Aydin, 2017: p. 549). Rhoades and Eisenberger (2002: p. 698) stated that organizational support within the scope of social exchange increases organizational commitment, job satisfaction and intention to remain. Kerse and Karabey (2017: p. 377) stated that the perception of organizational support should be evaluated in terms of 
employees. When evaluated by the employees, it is stated that organizational support is related with organizational justice, communication, job satisfaction, organizational commitment, and organizational citizenship behavior (Tanrıverdi \& Kilıç, 2016: p. 7). When evaluated in this context, it can be said that perceived organizational support is effective on both career success and intention to remain.

\subsection{Subjective Career Success}

It is required for employees to possess the information, skills, and competencies to fulfill the requirements stated in job definition. While organizations strive to employ qualified personnel, people also want to work in a qualified organization and rise in the career ladder of the organization where they belong.

Career, which is an important concept in business life, is defined as a long-term job or profession of a person, time spent in a job or profession (https://www.merriam-webster.com). Besides while career enables employees to earn their living, status is explained as a concept that provides progress and internal satisfaction. According to Şimşek (1999: p. 334) career is to advance in a chosen profession and as a result, earn more money, take responsibility, gain dignity, strength and reputation. Bingöl (2004: p. 245) has defined career as the work that people perform throughout their business life, and the developments and achievements they have in their working lives.

Career in business life is an important concept for both employees and organizations. When considered in terms of employees, career helps employees to know themselves individually, identify their strengths and weaknesses and interests, have information about vacancies in their current organization, and to make planning for their targeted career. When considered in terms of organizations, career helps identify qualified employees who are considered to be needed in the future and include them in the employment plan (Sadullah et al., 2015: p. 269).

It has been stated that the success of the employees regarding their career is also effective on the success of the organization because they are workers of the organization (Ng et al., 2005: p. 370) and it is specified that human capital, the organization's support for employees, socio-demographic characteristics and personality traits are effective on career success (Kaya, 2018: p. 12).

Career success is divided into objective career success and subjective career success. While objective career success is measured according to objective criteria such as income, control area and hierarchical progress of one's career; subjective career success results from evaluating a person's career according to personal criteria. In this context, it is necessary to state the relationship between career satisfaction and career success. Career satisfaction may be high due to a motivating job, but may not be sufficient for perception of success. Career satisfaction is one of the types of job satisfaction (Lounsbury et al., 2008). Career satisfaction is an emotional situation that arises from the combination of employees' aspirations about the future, interest in the job and employment conditions and 
abilities (Anafarta \& Y1lmaz, 2019: p. 2946).

The measure of subjective career success is typically expressed as attitudes, feelings and perceptions of how individuals feel about their success rather than their objective success ( $\mathrm{Gu} \& \mathrm{Su}, 2016:$ p. 229). It is stated that organizational and personal factors are effective on subjective career success. While training and development opportunities provided by the organization and organization support are counted among organizational factors, personal characteristics, abilities, educational level, experience, knowledge, social capital and demographic characteristics are listed among the personal factors (Otluoğlu, 2014: p. 351).

In their study, Gattiker and Larwood (1986) have evaluated subjective career success in five dimensions namely, business success, relationship success, economic status, hierarchical success and life success. Parker and Arthur (2002: p. 105) have developed a three-dimensional scale whereas, Shockley (2005: 128) has developed an eight dimentional scale. In this study, an eight-dimensional scale developed by Budak and Gürbüz (2017), constituting of dimensions namely recognition, meaningfulness of work, impact, quality of work, authenticity, personal life, growth and development, has been used.

\subsection{Intention to Remain}

Intention can be defined as the form of behavior that has not yet occurred but which is in thought form. It has been stated that intention is a psychological premise for actual behavior (Ajzen \& Fishbein, 1980). Here, the intention to remain can be expressed as the fact that the employee is still thinking about continuing to work in the organization where he is working. The intention to remain at their work is defined as the long-term intention of the employees in their current employment relationship with their current employers (Shahid, 2018: p. 59). It can be stated that the intention to remain at work is the opposite of the intention to leave (Johari et al., 2012: p. 398). Employees who have no intention to remain at work or who have the intention to leave, means that it is likely for the employees to permanently leave the organization in the near future (Vandenberg \& Nelson, 1999). When it is evaluated in this respect it can be stated that the intention to remain is based on planned behavioral theory defined as the fact that intention of a person to realize a certain behavior is determinant of said behavior (Ajzen \& Fishbein, 1980).

On the other hand, the intention to remain can be expressed as a result of comparing the gains of the employee from the job he performs and the losses he will be faced with in case of leaving (Steel \& Lounsbury, 2009). Hence, if his losses will be more than his gains if he leaves his work, it will be expected for the person to remain in his work (Seçkin \& Çoban, 2017: p. 137).

The organization's efforts to retain employees are also important in the formation of employees' intention to remain and in keeping employees in the organization. Ensuring that the employees stay in the organization is examined in two groups as internal and external factors (Sıldıroğlu Erdemli \& Toptaş, 2016: 
p. 556). While internal factors consist of factors such as job satisfaction, job stress, motivation, justice, perception of organizational support and commitment, external factors called organization's opportunities and management practices provided to employees are factors such as reward, payment, business environment, recognition, communication, leadership and autonomy. In this context, it is evaluated that the working environment provided by the organization, organizational climate and organizational support is important for the perceptions of the employees towards the organization. Besides it can also be said that in case the management recognizes the employees, necessary measures can be taken to foresee the intention of employees to leave their work (Shahid, 2018: p. 59), and to take measures to ensure that they remain at work.

\subsection{Relationship between the Variables}

Brown and Roloff (2015) stated that as the organizational support perceptions of the employees strengthen positively, the intention to stay at work increases. In the research conducted on bank employees, it was determined that there was a significant relationship between employees' perceptions of organizational support and intention to leave. It was stated that with the help of the organizational commitment and commitment of the employees, the intention to leave can be reduced, in other words, the intention to remain can be increased (Nadeem et al., 2019: p. 222). Tews et al. (2013: p. 633) stated that the support of colleagues is effective on employees' intention to remain.

In a study conducted by Demir (2012: p. 49) on the employees of the airport ground handling company, it was found that positive organizational support reduced employees' intention to leave. In other words, it can be said that organizational support increases the intention to remain.

In a study on foreign employees, a significant relationship was detected between perceived organizational support and intention to remain (Cao et al., 2014). Leader's support in organizations can have positive effects on employee satisfaction and performance. In the study they conducted, De Coninck and Johnson (2009: 340) found that the support given by the sales managers to the sales staff positively affects the performance of the employees (Kale, 2015: p. 105). In the study conducted by Zhou et al. (2015: p. 251), it has been determined that employees' perceptions of organizational support have a mediating role in the relationship between psychological capital and subjective career success. Özdevecioğlu (2003: p. 116) stated that employees who feel the support of the organization will have higher level of commitment to their jobs, organizations and managers, and will not consider leaving their current jobs and organization (Özdevecioğlu, 2003: p. 116). It can be said that these findings will increase the motivation, subjective career success of employees and intention to stay at work.

When the studies conducted on the subject in the literature are examined, it is evaluated that there is a positive relationship between perceived organizational 
support and intention of employees to remain. This relationship has been tried to be examined with the following hypothesis created within the scope of the study;

$H_{1}$ : There is a positive and significant relationship between variables of perceived organizational support and intention to remain.

The positive perception of organizational support of the employees has a significant impact on their success. The organization's concern with the happiness and well-being of the employees (Rhoades \& Eisenberger, 2002), supporting them whenever they need strengthens the bonds of employees with their organizations and increases their performance (Bekmezci et al., 2020). Subjective career success consists of employees' individual thoughts about their career. In the study conducted by Seema and Sujatha (2017), a significant relationship was found between employees' perception of organizational support and career success. Yu (2010) concluded in their study that organizational support affects career success. Dose et al. (2019) determined that the perceived organizational support by meeting autonomy and competence needs has an indirect effect on subjective career success.

The hypothesis based on the information in the literature to determine the relationship between perceived organizational support and subjective career success can be expressed as follows;

$\mathrm{H}_{2}$ : There is a positive and significant relationship between variables of perceived organizational support and subjective career success.

In the research conducted by Anafarta and Yilmaz (2019: p. 2944) on employees of the banking sector, a negative relationship was found between career satisfaction and intention to leave. Singh (2018) has shown that career management practices in the organization increase the career satisfaction of employees and decrease the intention to leave the organization. Martins et al. (2002) stated in their study that career satisfaction increases the happiness of employees and positively affects their commitment to work (Anafarta \& Y1lmaz, 2019: p. 2945). Therefore, it has been evaluated that those who are happy in their jobs will be committed to their jobs and their intention to stay at work will be improved.

In the study conducted in the aviation sector by Kaya (2018: p. 119), it was determined that if the employees were given opportunities for career development, the organizational commitment and satisfaction level of their employees increased and their intention to quit decreased.

In a study conducted by Sökmen and Aydıntan (2016: p. 251) in a public enterprise, it was found that the career compatibility and career optimism of the employees, which can be evaluated as subjective career success, have a negative and meaningful effect on the intention to leave. Therefore, employees' having positive feelings and thoughts about their career may increase their intention to stay at work. Simo et al. (2010: p. 144) found a positive relationship between subjective career success and intention to stay. Nadeem et al. (2019: p. 224) stated that motivation factors increase the intention to stay at work. In this con- 
text, subjective career success can be evaluated as an important factor that motivates people and it can be said that subjective career success increases the intention to remain.

The hypothesis created to determine the relationship between subjective career success and intention to remain in the light of this information is as follows;

$\mathrm{H}_{3}$ : There is a positive and significant relationship between variables of subjective career success and intention to remain.

In the study they conducted on the banking sector employees belonging to generation Y, Othman et al. (2019: p. 86) stated that emotional needs have a significant effect on employees' intention to stay at work and that perceived organizational support has an intermediary role in this relationship and that a policy implementation that will cover employees' emotional needs and their valuable contributions to the organization may increase their intention to remain.

Since it is evaluated that subjective career success will also be effective in the relationship between organizational support perceived by employees and the intention to remain, the hypothesis created for this relationship can be expressed as follows;

$H_{4}$ : Subjective career success variable plays an mediating role in the relationship between perceived organizational support and intention to remain.

\section{Method}

\subsection{Research Model}

In the study, the relational scanning model, which is one of the quantitative research methods widely used in the literature, has been used. In this context, the relationship between variables of perceived organizational support (POS), subjective career success (SCS), intention to remain (ITR) and whether SCS has a mediating role regarding the impact of POS on ITR have been investigated. The research model created within the scope of the said objective is given in Figure 1.

The hypotheses of the study created based on the research model are as follows:

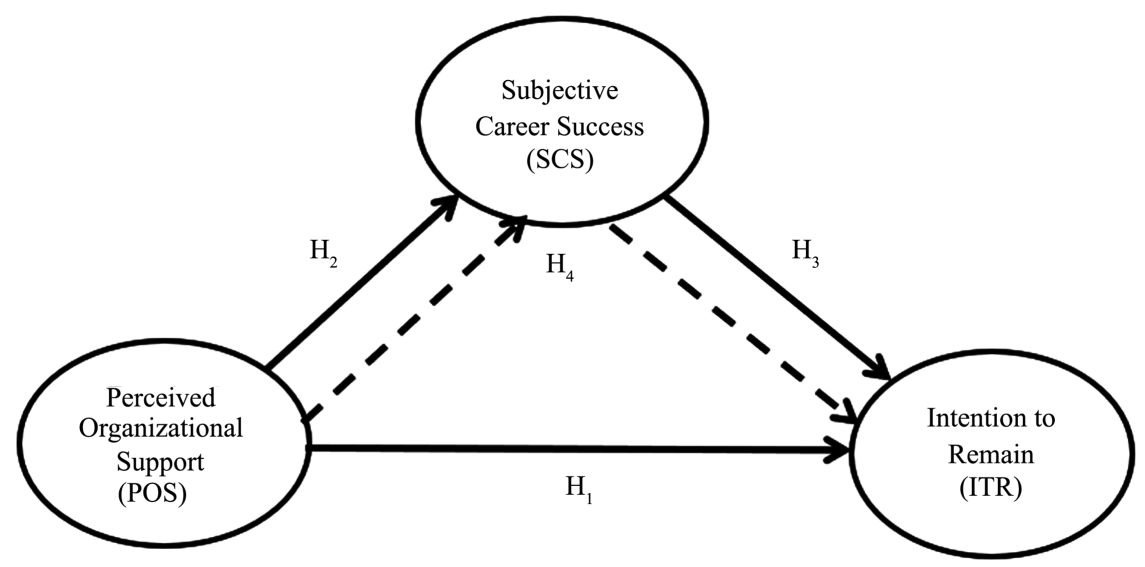

Figure 1. Research model. 
$H_{1}$ : There is a positive and significant relationship between variables of perceived organizational support and intention to remain.

$\mathrm{H}_{2}$ : There is a positive and significant relationship between variables of perceived organizational support and subjective career success.

$H_{3}$ : There is a positive and significant relationship between variables of subjective career success and intention to remain.

$H_{4}$ : Subjective career success variable plays a mediating role in the relationship between perceived organizational support and intention to remain.

\subsection{Purpose of the Study}

The purpose of the study is to test the research model established between the variables of POS, SCS, ITR on a sample of academics working at foundation universities located in Ankara and Mersin.

\subsection{Main Mass and Sample of Research}

The data used in the study were collected with three scales applied to academics working at foundation universities in Ankara and Mersin. In the collection of data, academicians were preferred because they could give more objective answers to the questions due to the high education levels. In the period when the data were collected, a total of 457 academicians were working in five foundation universities in Ankara and Mersin provinces. Therefore, the main population of the study is composed of academicians working in foundation universities in Ankara and Mersin. The sample of the study has been calculated by using the Formula (1).

$$
n=\frac{N p q Z^{2}}{(N-1) d^{2}+p q Z^{2}}
$$

In Formula (1); symbols were used namely; $n$ : Number of samples, $N$ : Number of populations, $p$ : Frequency (probability) of the event to be examined, $q$ : Frequency of the event to be examined $(1-p), Z$ : Theoretical value $(\%(1-Z$ test value at $\alpha$ ) level, $\alpha=$ significance level, $d$ : It is symbolized as \pm deviation (error (tolerance) margin) to be made according to the frequency of occurrence of the event. This formula is used if the main mass number is known. In the study, the proportion of the respondents was taken as 0.5 to work with a large sample, and sample size to represent the main mass with importance level of $5 \%$ and error rate of $5 \%$ was found as;

$$
n=\frac{(457 \times 0.5 \times 0.5 \times 1.96 \times 1.96)=438.90}{((457-1) \times 0.05 \times 0.05)=1.14+(0.5 \times 0.5 \times 1.96 \times 1.96)=0.96}=209
$$

In the formation of sample, easy sampling method, being random and easily reachable, has been used. Because, it is stated in the literature that when the data is required to be obtained in a short time and with minimum cost, the data can be collected by easy sampling method, which is not based on probability (Eygü \& Kilınç, 2019: p. 1027). 
150 academicians have participated in the survey, 68 of whom were women (45\%) and 82 of whom were men (55\%); 82 of whom are married (55\%) and 68 of whom are single (45\%), 26 of whom were associates (17\%), 52 of whom were research assistants (35\%) and 72 of whom were lecturers (48\%).

\subsection{Measurement Tools}

The data needed to test the model established in the study was gathered with three measurement tools. Information about the measurement tools is given below.

Perceived Organizational Support (POS) Scale: The POS Scale was created by Eisenberger et al. (1986) and was adapted to Turkish by Giray and Şahin (2012). While Eisenberger et al. (1986) have prepared forms with 36 questions, 17 questions and 8 questions as 7-point Likert type, in its adaptation to Turkish by Giray and Şahin (2012) have created a form with 12 questions (one sub-dimensional, 6 questions coded in reverse). As a result of the explanatory factor analysis conducted by Giray and Şahin (2012), it was stated that the items were collected in a single factor, had 6.76 eigenvalue, explained $56.2 \%$ of the variance and the Cronbach's alpha coefficient was 0.93 .

Subjective Career Success (SCS) Scale: SCS scale was created by Shockley et al. (2015) and it was adapted to Turkish by Budak and Gürbüz (2017). In this scale, there are eight sub-dimensions (1) Recognition, 2) Job Significance, 3) Effect, 4) Job Quality, 5) Authentic, 6) Personal Life, 7) Growth and Development and 8. Satisfaction) and 24 questions (three questions in each sub-dimension). Cronbach's alpha coefficient value concerning the whole scale was determined as 0.91 in the study conducted by Shockley et al. (2015) and in the study conducted by Budak and Gürbüz (2017), it was calculated as 0.91 in the sample consisting of employees in the public sector and as 0.94 in the sample consisting of employees in the private sector.

Intention to Remain (ITR) Scale: ITR Scale was developed by Gellatly et al. (2006) and the said scale was used in studies of Ülker (2007) and Karadeniz (2010) conducted in the field of social sciences in Turkish. There are 3 questions (one sub-dimension) in the scale. Cronbach's alpha coefficient value of the scale was found as 0.73 by Gellatly et al. (2006), as 0.69 by Ülker (2007) and as 0.80 by Karadeniz (2010).

Since all three scales were previously adapted to Turkish, no action was taken regarding the scope and logical validity of the question items of the scales. In this study, factor analysis was performed only to determine whether the data fit the structure of the scales and validity and reliability of scales have been calculated.

\subsection{Stages of Study}

The research was carried out in three stages. In the first stage, it was mentioned about the necessary studies to ensure the validity and reliability of the scales; in the second stage it was mentioned about the analysis of the model being estab- 
lished and in the third stage the findings obtained from the analysis were stated.

\subsection{Research Method}

In the literature, the covariance-based structural equation model (CB-SEM) is used, which is a generally parametric method for relationships between latent variables. In order to use the CB-SEM method, assumptions such as normal distribution of data, number of samples' being more than 300, and variables' being linear should be provided (Bayram, 2010). In the research, although the questionnaire was sent to 300 academics, response was obtained from 191 people and 41 questionnaires that were missing or incorrect were filled out and hence, 150 questionnaires were analyzed. This number is below the least value of 209 that is calculated as per the main mass.

In addition, the multivariate normal distribution test (Henze-Zirkler Test) conducted in the $\mathrm{R}$ programming language should provide multivariate normal distribution while the data in the study did not disperse multivariate normal distribution (HZ test: 11.5873, $p(0.000)<0.05$ and MVN: NO). Although several studies have been carried out to ensure the normal distribution of data by using conversion methods such as square root, logarithmic and squaring, the multivariate normal distribution of the study data has not been achieved. For the reasons explained, the structural equation model based on variance, in other words, Partial Least Square Structural Equation Model (PLS-SEM) was used. PLS-SEM is a nonparametric method used when the above-mentioned specifications are not met, and although the minimum sample size has not reached 209, it does not affect the results of the analyzes made with PLS-SEM (Hair et al, 2017).

The analysis of the model, which was established in order to achieve the purpose determined in the study, was carried out in two stages in the Smart PLS package program. In the first stage, the validity and reliability of the scales were checked by factor analysis, and in the second stage, the structure of the model established by road analysis was tested.

\subsection{Validity and Reliability Studies of Scales}

Within the scope of validity studies of the scales used in the study;

Firstly, expert opinion (20 experts) was consulted for its scope and logical validity, it was determined that the items of the scale received Content Validity Ratio (CVR) values above 0.42 , which was the reference value of 0.05 significance level, and all of the Content Validity Index (CVI) values of the scale were determined to receive values above the reference value of 0.67 . For this reason, it was decided to use the scales in the same way without any changes.

Subsequently, the construct validity, reliability analysis and path analysis of the model were performed, respectively. All of these analyzes can be done on the model installed in the SmartPLS package program (Compeau \& Higgins, 1995: p. 128). Hair et al. (2017), indicate that a 3-step process can be followed in PLS-SEM analysis. These stages are namely; determining model specifications 
(determining the relationships between hidden variables and variables that can be measured with variables), evaluation of the external model (control of the validity and reliability of the model) and evaluation of the internal model (evaluation of the structure of the model). In this context, firstly factor analysis and then path analysis related to scales were made in SmartPLS package program. In the first attempt in the analysis of the factor, due to the reason that factor loads of POS2, POS6 and POS11 measurable variables relating with POS variable among factor loads were found to be very low, these items were removed from analysis and second experiment was conducted. Factor loads in the PLS-SEM method show the degree of relevance of the expressions in the scales and it is preferred that these values obtained in the SmartPLS package program be above $70 \%$. In this context, after the second attempt, the research model established in the SmartPLS package program, which includes POS Scale (1 sub-dimension and 9 items), SCS Scale (8 sub-dimensions and 3 items in each sub-dimension), and the ITR Scale (1 sub-dimension and 3 items). Its formal representation is given in Figure 2.

When factor loads of the research (measurement) model in Figure 2 are examined; it is seen that all factor loads are above the reference value in the literature $(70 \%)$ or very close (POS1, POS7, POS8, POS9). Therefore, it was decided to use the model in Figure 2 exactly.

In addition to looking at the factor loads related to the validity and reliability of the model installed in the SmartPLS package program, internal consistency coefficient (Cronbach's Alpha Coefficient) and convergence validity (Data Consistency (Rho_A) Coefficient, Combined Reliability Coefficient and AVE (Average Variance Extracted) values and decomposition validity (Fornell-Larcker Criteria and Heterotrait Monotrait Rate) are also considered. The statistical results calculated in the SmartPLS package program regarding the validity and reliability of the model established in this scope are given in Table 1.

Table 1. Validity and reliability statistics of scales.

\begin{tabular}{ccccc}
\hline Scales & $\begin{array}{c}\text { Cronbach's } \\
\text { Alpha } \\
\text { Coefficient }>\text { 0.70* }\end{array}$ & $\begin{array}{c}\text { Data } \\
\text { Consistency } \\
\text { Coefficient }>\text { 0.70* }\end{array}$ & $\begin{array}{c}\text { Combined } \\
\text { Confidence } \\
\text { Coefficient }>0.70^{*}\end{array}$ & $\begin{array}{c}\text { Average } \\
\text { Variance Extracted } \\
\mathbf{0 . 5 0 *}\end{array}$ \\
\hline POS & 0.902 & 0.928 & 0.919 & 0.562 \\
SCS & 0.961 & 0.965 & 0.965 & 0.537 \\
SCS1 & 0.914 & 0.917 & 0.946 & 0.854 \\
SCS2 & 0.904 & 0.906 & 0.939 & 0.838 \\
SCS3 & 0.891 & 0.895 & 0.932 & 0.822 \\
SCS4 & 0.859 & 0.860 & 0.914 & 0.780 \\
SCS5 & 0.857 & 0.874 & 0.912 & 0.776 \\
SCS6 & 0.821 & 0.822 & 0.893 & 0.736 \\
SCS7 & 0.932 & 0.934 & 0.956 & 0.880 \\
SCS8 & 0.944 & 0.948 & 0.964 & 0.899 \\
ITR & 0.824 & 0.839 & 0.894 & 0.738 \\
\hline
\end{tabular}

${ }^{*}$ Fornell and Larcker (1981). 


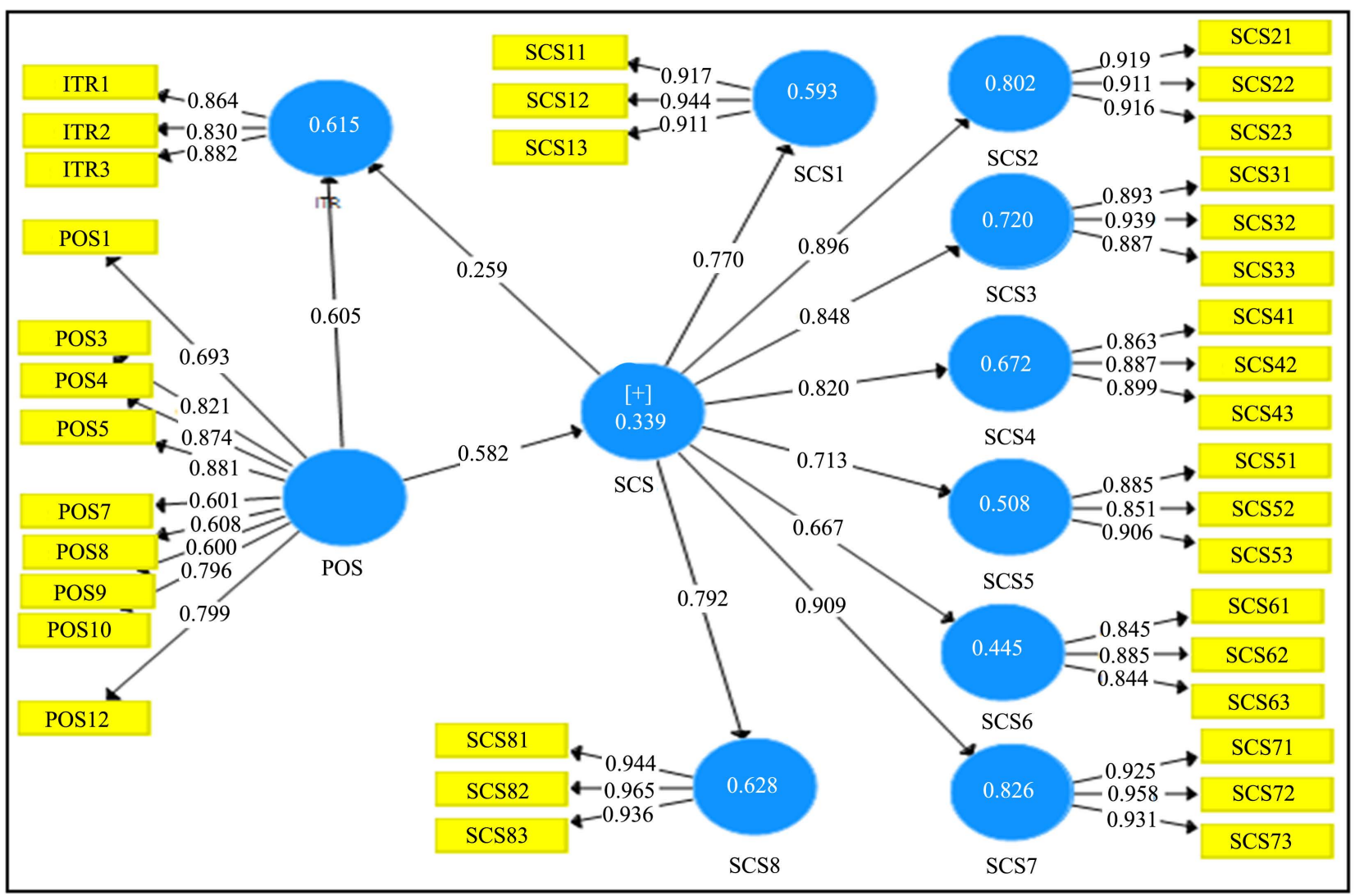

Figure 2. Research (measurement) model in SmartPLS package program.

When the statistics related to the validity and reliability of the model in Table 1 are examined; it is seen that these values are above the threshold levels. By means of these statistical data, it is concluded that the scales have sufficient internal consistency and convergence validity.

In determining the separation validity in the study, Fornell-Larcker criteria proposed by Fornell and Larcker (1981) and Henseler et al. (2015) and Heterotrait-Monotrait ratio have been used. According to the Fornell-Larcker criteria, the square root of the Extracted Common Variance values should be higher than the correlations between the structures in the study. Heterotrait-Monotrait ratio is the ratio of mean of the correlations of the expressions of all variables in the research to the geometric means of the correlations of expressions of the same variable and it is preferred for this ratio to be smaller than 0.85 or 0.90 . The calculated values related to the decomposition validity of the model established in this context are given in Table 2.

When the values related to Fornell-Larcker criteria and Heterotrait-Monotrait ratio within the scope of decomposition validity in Table 2 are examined, it is seen that these values are in agreement with the reference values in the literature. Furthermore, it was determined that there is a meaningful, same-directional and strong level relationship ( $\mathrm{r}=0.582, p<0.05$ ) between POS and SCS, a meaningful, same-directional and medium-level relationship $(\mathrm{r}=0.757, p<0.05)$ 
Table 2. Decomposition validity coefficients of the model.

\begin{tabular}{cccccccc}
\hline & \multicolumn{3}{c}{ Fornell-Larcker Criteria } & \multicolumn{5}{c}{ Heterotrait-Monotrait Ratio } \\
\hline Scales & POS & SCS & ITR & Scales & POS & SCS & ITR \\
\hline POS & $0.750^{*}$ & & & POS & & \\
SCS & $0.582^{* *}$ & $0.733^{*}$ & & SCS & 0.602 & & \\
ITR & $0.757^{* *}$ & $0.611^{* *}$ & $859^{*}$ & ITR & 0.823 & 0.682 & \\
\hline
\end{tabular}

${ }^{*}$ Calculated values are the square root of the Extracted Common Variance values. ${ }^{*}$ Calculated values are correlation coefficients between latent variables.

between POS and ITR, and a meaningful, same-directional and strong level relationship ( $\mathrm{r}=0.611, p<0.05)$ between SCS and ITR.

The last statistics to be considered within the scope of the validity and reliability of the model are the VIF values and $\mathrm{R}^{2}$ values, which are goodness of fit values. SRMR and NFI goodness of fit values are used in PLS-SEM models as goodness of fit values. In the model, SRMR goodness of fit value is between 0 and 0.08 and NFI goodness of fit is between 0.90 - 1.00 (Hair et al., 2017). While VIF values provide information about the multiple connections between independent variables in the established model, $\mathrm{R}^{2}$ is a statistical value used in the evaluation of the internal model and expresses how much of the dependent change in percent by independent variables is explained. In addition, $\mathrm{R}^{2}$ is one of the basic evaluation criteria that should be used in evaluating the structural model with road coefficients and significance. The calculated goodness of fit values of the model established within this scope are namely, SRMR: 0.022 and NFI: 0.907 and VIF values and $\mathrm{R}^{2}$ values are given in Table 3.

When SRMR and NFI goodness of fit values are examined; it was observed that the goodness of fit values was among the reference values (SRMR $<0.08$ and NFI $>0.90$ ) and it was concluded that the model established was a well-fit model.

When VIF values and $\mathrm{R}^{2}$ values in Table 3 are examined; since all the VIF values between the variables are lower than the reference value of 5 in the literature, it is seen that there is no multiple connection problem between the variables and the obtained parameters give reliable results and according to $\mathrm{R}^{2}$ values, in the first model in which POS variable is independent variable, SCS variable is dependent variable, it was determined that POS could explain SCS by the ratio of $33.9 \%$ and that in the second model, where the POS variable is an independent variable and the ITR variable is this time dependent variable, it was determined that POS could explain SCS with a ratio of $61.5 \%$. These values are above $26 \%$, which can be accepted as the reference value in the literature, and that accordingly, it was reached to the conclusion that these were appropriate values. ( $R^{2}$ is small if it takes values between $0.02 \leq R^{2}<0.13$; It is categorized as medium if it takes values between $0.13 \leq \mathrm{R}^{2}<0.26$ and it is considered to have a large effect if it takes values as $0.26 \leq \mathrm{R}^{2}$ ) (Cohen, 1988). 
Table 3. VIF and $\mathrm{R}^{2}$ values of established module.

\begin{tabular}{cccccc}
\hline & VIF values & \multicolumn{3}{c}{$\mathrm{R}^{2}$ values } \\
\hline Scales & SCS & ITR & Scales & $\mathbf{R}^{2}$ & Correction $\mathbf{R}^{2}$ \\
\hline POS & & 2.154 & ITR & 0.615 & 0.606 \\
SCS & & 2.257 & SCS & 0.339 & 0.357 \\
\hline
\end{tabular}

\subsection{Structural Examination of Established Model}

In order to test the structural examination of the model being established, in the SmartPLS package program, which allows a clear calculation of each variable scores PLS-SEM method road analysis was applied and in order to evaluate the statistical significance of the relationships defined in this scope, the resampling method (bootstrapping resampling methods) was used (Chin, 1998).

The resampling method involves generating randomly selected sub-sampling cases to replace the original data (Hair et al., 2017). Direct impact values or path coefficients $(\beta)$ and indirect impact values calculated for each randomly selected sub-sample are calculated and these values are given in Table 4 and Table 5. Standardized values of latent variables were used in the calculation of the values, as in the relationship analysis.

When the calculated path coefficient (direct effect values) values of the model in Table 4 are examined; it was reached to the conclusion that there was a meaningful and positive directional impact of POS on SCS $(\beta=0.593, p(0.000)<$ $0.05)$, of POS on ITR $(\beta=0.594, p(0.000)<0.05)$ and of SCS on ITR $(\beta=0.273$, $p(0.042)<0.05) . H_{1}, H_{2}$ and $H_{3}$ hypotheses were accepted from the hypotheses established in this context.

When the indirect impact values of the variables in the model set up in Table 5 are examined; it was determined that the indirect effect path between POS, SCS and ITR is meaningless $(\beta=0.167, p(0.102)>0.05)$. When this result is evaluated together with the direct effect values among the variables in Table 5, it reveals that the SCS does not have an intermediary role between POS and ITR. Therefore, it was decided not to accept the $H_{4}$ hypothesis from among the established hypotheses.

\section{Findings}

In the study first of all three scales being used to collect the data have been controlled with respect to their context and logical validity, even though they have been used in various studies in Turkey and it was decided not to make any changes in relation to questions regarding the scales. Subsequently, the model established in the SmartPLS package program was tested within the scope of the construct validity and reliability of three scales. In the SmartPLS package program, the construct validity and reliability analysis of the scales were made on the model established and factor loads, Cronbach's alpha coefficient values, data consistency coefficient, combined reliability coefficient, common variances 
Table 4. Path Coefficients of the model established (Direct effect).

\begin{tabular}{cccccc}
\hline Scales & $\begin{array}{c}\text { Original Standardized } \\
\text { Sample } \beta \text { Coefficient }\end{array}$ & $\begin{array}{c}\text { Standardized Sample } \\
\boldsymbol{\beta} \text { Coefficient }\end{array}$ & $\begin{array}{c}\text { Standard } \\
\text { Deviation }\end{array}$ & T & $\boldsymbol{P}$ \\
\hline $\mathrm{POS} \rightarrow \mathrm{SCS}$ & 0.582 & 0.593 & 0.098 & 5.966 & 0.000 \\
$\mathrm{POS} \rightarrow \mathrm{ITR}$ & 0.605 & 0.594 & 0.119 & 5.103 & 0.000 \\
$\mathrm{SCS} \rightarrow \mathrm{ITR}$ & 0.259 & 0.273 & 0.026 & 2.041 & 0.042 \\
\hline
\end{tabular}

Table 5. Indirect impact value of the model established.

\begin{tabular}{|c|c|c|c|c|c|}
\hline Scales & $\begin{array}{l}\text { Original Standardized } \\
\text { Sample } \beta \text { Coefficient }\end{array}$ & $\begin{array}{c}\text { Standardized Sample } \\
\beta \text { Coefficient }\end{array}$ & $\begin{array}{l}\text { Standard } \\
\text { Deviation }\end{array}$ & $\mathrm{T}$ & $P$ \\
\hline $\mathrm{POS} \rightarrow \mathrm{SCS} \rightarrow \mathrm{ITR}$ & 0.150 & 0.167 & 0.092 & 1.641 & 0.102 \\
\hline
\end{tabular}

extracted, Fornell-Larcker Criteria, Heterotrait-Monotrait Ratios, correlation coefficients, VIF and $\mathrm{R}^{2}$ values were examined. Factor loads of scales were found as $0.600-0.889$ for POS scale, $0.844-0.965$ for SCS scale, $0.827-0.883$ for ITR scale; Cronbach's alpha coefficient values were found in the range of 0.821 0.961; data consistency coefficients were found in the range of $0.822-0.965$; combined confidence coefficients were found in the range of $0.893-0.965$; common variance values were found between 0.537 - 0.899; Fornell-Larcker Criteria values were found between 0.733 - 0.859 ; correlation coefficients were found between 0.582 - 0.757; Heterotrait-Monotrait Ratios were found in the range of $0.602-0.823$; goodness fit values were found as SRMR: 0.022 , NFI: 0.907; VIF values were found as 2.154 and 2.257; $\mathrm{R}^{2}$ values were found as 0.615 and 0.339 . It has been determined that all of the found values are in accordance with the reference values in the literature, and as a result, it has been decided that the model established is a valid and reliable model and after these procedures, the structure of the model established has been examined.

Path analysis method and resampling were used during the examination of the model's structure. In this context, $\beta$ coefficients, $t$ tests and significance coefficients of the variables, direct and indirect interference values between the variables were calculated. As a result of calculations being made, it was determined that direct interactions between POS $\rightarrow$ SCS $(\beta=0.593, p<0.05)$, SCS $\rightarrow$ ITR $(\beta$ $=0.594, p<0.05)$ and POS $\rightarrow \operatorname{ITR}(\beta=0.273, p<0.05)$ variables were meaningful but that indirect interaction between POS $\rightarrow$ SCS $\rightarrow$ ITR $(\beta=0.167, p>0.05)$ variables was not meaningful. In this context, $H_{1}, H_{2}$ and $H_{3}$ hypotheses were accepted, but $H_{4}$ hypothesis was not accepted. Therefore, according to the results obtained, it was concluded that SCS in the relationship between POS and ITR does not have an intermediary role.

\section{Conclusion}

When the analysis results are examined; a positive and significant relationship was detected between POS and ITR and SCS. In order for organizations to be 
successful, their employees must be qualified and supported by their colleagues and managers. This support may include material and spiritual elements. The organization's belief in the contribution of its employees, its support for its employees, its support for all levels of employees will make employees feel safe. Employees' being supported by their colleagues and managers will make the employees feel valuable. This will positively affect employees' ITR. Therefore, it is very important to support the organization in order to increase the intention of qualified personnel to remain at work. This will also create a sense of accomplishment suited to the individual characteristics of the employee. Therefore, SCS will increase the ITR.

In the research conducted, it was seen that SCS did not have a mediating effect between POS and ITR, contrary to expectations. The mediating effect is a variable that helps to understand how and why the relationship between the two variables occurs. When evaluated in this context, it was seen that POS did not increase the ITR due to the effect of SCS, in other words, when SCS was taken into account, it did not change the effect of POS on the ITR. In this context, it can be stated that POS is an important variable both in terms of SCS and ITR.

This research also has some limitations. It is an important limitation that the research was conducted only on academics. Because academics are the intellectuals of the society. Academics have a duty to educate university students, conduct research and inform the society. It is expected that academicians are supported by the university administration and the state while fulfilling these duties. In addition, the motivation for research and enlightenment for academics is more important than career success. Because of this, different results can be obtained if the research is applied in other sectors. Another important limitation is that the research is not longitudinal. Findings obtained in different steps may be more revealing.

\section{Conflicts of Interest}

The authors declare no conflicts of interest regarding the publication of this paper.

\section{References}

Abou-Moghli, A. (2015). The Role of Organizational Support in Improving Employees Performance. International Business Research, 8, 198-203. https://doi.org/10.5539/ibr.v8n2p198

Ajzen, I., \& Fishbein, M. (1980). Understanding Attitudes and Predicting Social Behavior. Englewood Cliffs, NJ: Prentice-Hall.

Allen, D., Shore, L. M., \& Griffeth, R. W. (2003). The Role of Perceived Organizational Support and Supportive Human Resource Practices in the Turnover Process. Journal of Management, 29, 99-118. https://doi.org/10.1177/014920630302900107

Anafarta, A., \& Yılmaz, Ö. (2019). The Mediating Role of Work Commitment in the Relationship between Career Satisfaction and Intention to Quit. Journal of Business Studies, 11, 2944-2959. https://doi.org/10.20491/isarder.2019.786 
Aydin, E. (2017). Social Exchange in the Context of Culture: A Theoretical Study. UIIIID-International Journal of Economic and Administrative Studies, 16, 547-562.

Babin, B. J., \& Boles, J. S. (1996). The Effects of Perceived Co-Worker Involvement and Supervisor Support on Service Provider Role Stress, Performance and Job Satisfaction. Journal of Retailing, 72, 57-75. https://doi.org/10.1016/S0022-4359(96)90005-6

Bayram, N. (2010). Introduction to Structural Equation Modeling. AMOS Applications. Ankara: Ezgi Bookstore.

Beheshtifar, M., Ali-Nehzad, H., \& Nekoie-Moghadam, M. (2012). Investigation of Perceived Organizational Support on Employees' Positive Attitudes toward Work. Interdisciplinary Journal of Contemporary Research in Business, 4, 432-442.

Bekmezci, M., Orçanlı, K., \& Fırat, Z. M. (2020). The Mediating Role of Organizational Support Perception in the Relationship between Psychological Capital and Subjective Career Success. Atatürk University Journal of Economic and Administrative Sciences, 34, 853-876.

Bingöl, D. (2004). Human Resources Management. İstanbul: Beta.

Blau, H. (1964). The Impossible Theater: A Manifesto. New York: Macmillan.

Brown, L. A., \& Roloff, M. E. (2015). Perceived Organizational Support. In C. R. Berger, \& M. E. Roloff (Eds.), The International Encyclopedia of Interpersonal Communication (p. 6). New York: John Wiley \& Sons.

https://doi.org/10.1002/9781118540190.wbeic272

Cao, L., Hirschi, A., \& Deller, J. (2014). Perceived Organizational Support and Intention to Stay in Host Countries among Self-Initiated Expatriates: The Role of Career Satisfaction and Networks. The International Journal of Human Resource Management, 25, 2013-2032. https://doi.org/10.1080/09585192.2013.870290

Chin, W. W. (1998). The Partial Least Squares Approach to Structural Equation Modeling. Hillsdale, NJ: Lawrence Erlbaum Associates.

Cohen, J. (1988). Statistical Power Analysis for the Behavioral Sciences. Hillsdale, NJ: Lawrence Erlbaum Associates.

Compeau, D. R., \& Higgins, C. A. (1995). Application of Social Cognitive Theory to Training for Computer Skills. Information Systems Research, 6, 118-143. https://doi.org/10.1287/isre.6.2.118

Demir, M. (2012). The Relationship between Organizational Support, Organizational Commitment and Turnover Tendency: A Research for Airport Ground Services Businesses. "Business, Power" Industrial Relations and Human Resources Magazine, 14, 47-64.

Dervic, M. K., \& Dervic, S. (2017). Successful Leadership and Motivation Lead to Employee Satisfaction. In Management International Conference (pp. 569-580). http://www.hippocampus.si/ISBN/978-961-7023-71-8/179.pdf

Dose, E., Desrumaux, P., \& Bernaud, J. (2019). Effects of Perceived Organizational Support on Objective and Subjective Career Success via Need Satisfaction: A Study among French Psychologists. Journal of Employment Counseling, 56, 144-163. https://doi.org/10.1002/joec. 12130

Eisenberger, R., Huntington, R., Hutchison, S., \& Sowa, D. (1986). Survey of Perceived Organizational Support. Journal of Applied Psychology, 71, 500-507. https://doi.org/10.1037/0021-9010.71.3.500

Eygü, H., \& Kılınç, A. (2019). Investigation of Factors Affecting Socio-Economic Development Perception with the Help of Sequential Logit Model: Erzurum-Kayseri Exam- 
ple. Journal of Academic Value Studies, 5, 1023-1040.

https://doi.org/10.29228/javs.38807

Fornell, C., \& Larcker, D. F. (1981). Evaluating Structural Equation Models with Unobservable Variables and Measurement Error. Journal of Marketing Research, 18, 39-50. https://doi.org/10.1177/002224378101800104

Gattiker, U., \& Larwood, L. (1986). Subjective Career Success: A Study of Managers and Support Personnel. Journal of Business and Psychology, 1, 78-94. https://doi.org/10.1007/BF01018805

Gellatly, I. R., Meyer, J. P., \& Luchak, A. A. (2006). Combined Effects of the Three Commitment Components on Focal and Discretionary Behaviors: A Test of Meyer and Herscovitch's Propositions. Journal of Vocational Behavior, 69, 331-345. https://doi.org/10.1016/j.jvb.2005.12.005

Giray, M. D., \& Şahin, D. N. (2012). Perceived Organizational, Manager and Colleagues Support Scales: Validity and Reliability Study. Turkish Psychology Articles, 15, 10-11.

Gu, Q., \& Su, Y. (2016). How Does Objective Career Success Affect Subjective Career Success? The Moderating Role of Self-Awareness. Journal of Human Resource and Sustainability Studies, 4, 227-237. https://doi.org/10.4236/jhrss.2016.43025

Hair, J. F., Hult, G. T. M., Ringle, C. M., \& Sarstedt, M. A. (2017). Primer on Partial Least Squares Structural Equation Modeling (PLS-SEM) (2nd ed.). Thousand Oaks, CA: Sage. https://doi.org/10.15358/9783800653614

Henseler, J., Ringle, C. M., \& Sarstedt, M. (2015). A New Criterion for Assessing Discirimant Validity in Variance-Based Structural Equation Modeling. Journal of the Academy of Marketing Science, 43, 115-135. https://doi.org/10.1007/s11747-014-0403-8

https://www.merriam-webster.com

Johari, J., Yean, T. F., Zurina, A., Kırana, Y. K., \& Nassruddin, A. M. (2012). Promoting Employee Intention to Stay: Do Human Resource Management Practices Matter? International Journal of Economics and Management, 6, 396-416.

Kale, E. (2015). The Effects of Leader Support and Colleagues Support on Job Performance: The Mediator Role of Job Satisfaction and Life Satisfaction. International Journal of Economic and Administrative Studies, 7, 103-120.

Karadeniz, D. (2010). Examination of Organizational Culture in Terms of Organizational Commitment and Intention to Stay. Unpublished Master's Thesis, Bolu: Abant İzzet Baysal University Institute of Social Sciences.

Kaya, A. (2018). Testing the Effect of Career Development Process on Organizational Commitment and the Intention to Quit Using Structural Equation Modeling. Unpublished PhD Thesis, Çorum: Hitit University Institute of Social Sciences.

Kerse, G., \& Karabey, C. N. (2017). The Effect of Perceived Organizational Support on Organizational Identification: The Mediating Role of Organizational Cynicism. MANAS Journal of Social Research, 6, 375-398.

Kestek, S. B. (2016). The Relationship between Perceived Organizational Support and Organizational Trust. An Assessment on 5 Star Hotel Enterprises in Kuşadası. Unpublished Master's Thesis, Aydın: Adnan Menderes University Institute of Social Sciences.

Kim, G. W., Leong, K. J., \& Lee, Y. (2005). Effect of Service Orientation on Job Satisfaction, Organizational Commitment, and Intention of Leaving in a Casual Dining Chain Restaurant. Hospitality Management, 24, 171-193.

https://doi.org/10.1016/j.ijhm.2004.05.004

Lounsbury, J. W., Steel, R. P., Gibson, L. W., \& Drost, A. W. (2008). Personality Traits 
and Career Satisfaction of Human Resource Professionals. Journal Human Resource Development International, 11, 351-366. https://doi.org/10.1080/13678860802261215

Martins, L. L., Eddleston, K. A., \& Veiga, J. F. (2002). Moderators of the Relationship between Work-Family Conflict and Career Satisfaction. Academy of Management Journal, 45, 399-409. https://doi.org/10.2307/3069354

Nadeem, K., Khan, M. A., \& Imtiaz, M. N. (2019). Turnover Intention and Perceived Organizational Support; Mediating Role of Work Engagement and Organizational Commitment. European Scientific Journal, 15, 222-236. https://doi.org/10.19044/esj.2019.v15n10p222

Ng, T. W. H., Eby, L. T., Sorensen, K. L., \& Feldman, D. C. (2005). Predictors of Objective and Subjective Career Success: A Meta-Analysis. Personnel Psychology, 58, 367-408. https://doi.org/10.1111/j.1744-6570.2005.00515.x

Othman, Z., Singh, J., Singh, K., \& Hashim, R. A. (2019). Impact of Emotional Needs on Intention to Stay and the Mediating Role of Perceived Organizational Support: An Empirical Study of Gen Y Eemployees' in the Banking Sector in Malaysia. International Journal of Recent Technology and Engineering, 8, 86-94. https://doi.org/10.35940/ijrte.B1018.0982S919

Otluoğlu, K. Ö. (2014). A Study on the Effect of Career Commitment on Career Success. Journal of Management and Economics Studies, 23, 350-363.

Özdevecioğlu, M. (2003). A Research to Determine the Relationships between Perceived Organizational Support and Organizational Commitment. Dokuz Eylul University, Journal of Faculty of Economics and Administrative Sciences, 18, 113-130.

Parker, P., \& Arthur, M. (2002) Bringing "New Science" into Careers Research. Management, 5, 105-125. https://doi.org/10.3917/mana.051.0105

Rhoades, L., \& Eisenberger, R. (2002). Perceived Organizational Support: A Review of the Literature. Journal of Applied Psychology, 87, 698-714. https://doi.org/10.1037/0021-9010.87.4.698

Ring, J. K. (2011). The Effect of Perceived Organizational Support and Safety Climate on Voluntary Turnover in the Transportation Industry. International Journal of Business Research and Management, 1, 156-168.

Sadullah, Ö., Uyargil, C., Acar, A. C., \& Tüzüner, L. (2015). Human Resources Management. İstanbul: Beta Basım.

Seçkin, Ş. N., \& Çoban, R. (2017). The Regulatory Role of Perceived Alternative Job Opportunities in the Relationship between Wage Satisfaction, Intention to Stay and Life Satisfaction. Journal of Business Research-Türk, 9, 134-148.

https://doi.org/10.20491/isarder.2017.292

Seema, A., \& Sujatha, S. (2017). Perceived Organisational Support on Career Success: An Employee Perspective-An Empirical Study from an Indian Context. Middle East Journal of Management, 4, 22-38. https://doi.org/10.1504/MEJM.2017.083707

Shahid, A. (2018). Employee Intention to Stay: An Environment Based on Trust and Motivation. Journal of Management Research, 10, 57-71. https://doi.org/10.5296/jmr.v10i4.13680

Shockley, K. M., Ureksoy, H., \& Rodopman, O. B. (2015). Development of a New Scale to Measure Subjective Career Success: A Mixed-Methods Study. Journal of Organizational Behavior, 37, 128-153. https://doi.org/10.1002/job.2046

Sıldıroğlu Erdemli, Ö., \& Toptaş, B. (2016). Keeping an Employee at Work. Ankara: Ankara University Press. 
Simo, P., Enache, M., Leyes, J. M. S., \& Alarcon, V. F. (2010). Analysis of the Relation between Subjective Career Success, Organizational Commitment and the Intention to Leave the Organization. Transylvanian Review of Administrative Sciences, 29E, 144-158.

Şimşek, M. Ş. (1999). Yönetim ve Organizasyon. Ankara: Nobel.

Singh, S. (2018). Organizational Career Management Practices, Career Satisfaction, and Intention to Quit among Indian Employee: Examining the Moderating Effect of Four Types of Work Experience. Australian Journal of Career Development, 27, 150-159. https://doi.org/10.1177/1038416218768896

Sökmen, A., \& Aydintan, B. (2016). The Effect of Career Future Perception on Job Satisfaction and Intention to Quit: Research in a Public Institution. Journal of Business Studies, 8, 251-263. https://doi.org/10.20491/isarder.2016.199

Steel, R. P., \& Lounsbury, J. W. (2009). Turnover Process Models: Review and Synthesis of a Conceptual Literature. Human Resource Management Review, 19, 271-282. https://doi.org/10.1016/j.hrmr.2009.04.002

Tanrıverdi, H., \& Kılıç, N. (2016). Algılanan Örgütsel Destek ve Örgütsel Yabancılaşma Arasındaki İlişkinin İncelenmesi.

http://www.sdergi.hacettepe.edu.tr/makaleler/Tanriverdi-kilic-algilanan-orgutsel-deste k-02.2016.pdf

Tews, M. J., Michel, J. W., \& Ellingson, J. E. (2013). The Impact of Coworker Support on Employee Turnover in the Hospitality Industry. Group \& Organization Management, 38, 630-653. https://doi.org/10.1177/1059601113503039

Ülker, G. (2007). The Relationship between Organizational Commitment, Organizational Citizenship and Intention to Stay in the Organization: Examining These in Terms of Some Variables. Bolu Abant Izzet Baysal University Journal of Social Sciences Institute, 1, 227-248. https://doi.org/10.11616/AbantSbe.215

Uzoğlu, S. (2005). Corporate Communication Management. Eskişehir: Anatolian University.

Vandenberg, R. J., \& Nelson, J. B. (1999). Disaggregating the Motives Underlying Turnover Intentions: When Do Intentions Predict Turnover Behaviour? Human Relations, 52, 1313-1336. https://doi.org/10.1177/001872679905201005

Zhang, T. (2018). The Relationship of Perceived Organizational Support to Affective Commitment, Emotional Exhaustion and Turnover Intention-A Study of General Practitioners in Shanghai Community Health Centers in China. InstitutoUniversitario de Lisboa. https://repositorio.iscte-iul.pt

Zhou, W., Xie, B., Xin, X., Bai, G., \& Mao, R. (2015). A Meta-Analysis: Human Capital, Social Capital and Pychological Capital Affect County Employees Career Success. Acta Psychologica Sinica, 2, 251-263. https://doi.org/10.3724/SP.J.1041.2015.00251 